\title{
Hakekat Agama Dalam Perspektif Filsafat Perenial
}

\author{
Siti Amalia \\ UIN Sunan Kalijaga Yogyakarta \\ go.amalia@gmail.com
}

\begin{abstract}
Religion in life aside from functioning as a guide to life individually, religion also functions as an instrument in dealing with all differences. But now, religion in empirical reality begins to lose its social function. religious guidance that teaches to live peacefully and love one another, turns into a disaster that hates and destroys each other. Therefore, the discussion that will be examined in this article is: How does perennial philosophy explain the nature of religion? This problem will be examined by researchers with a descriptive approach, hermeneutics, and historical continuity. The nature of religion in the perspective of perennial philosophy can be seen from two sides, namely exoteric and esoteric. The exoteric side sees the nature of religion in terms of forms related to historicity, culture, customs, and ethnicity in certain societies. While the esoteric side sees the nature of religion by finding common ground to trace the historical chain of the growth of religion. The meeting point is located at the level of substance that has a transcendent unity. So, from an esoteric point of view the nature of religion is one not divided, but from this one radiates various truths. When the nature of religion is seen in different forms, then it is of relative value, because each adherent of the religion has an exclusive claim about the religion that is adhered to. But when religion is seen in transcendent unity, that is called absolute truth.
\end{abstract}

Kata kunci: Perenial Philosophy, Religion

Abstrak: $\quad$ Agama dalam kehidupan selain berfungsi sebagai pedoman hidup secara individu, agama juga berfungsi sebagai instrument dalam menyikapi seтиа perbedaan. Namun kini, agama dalam realitas empirik mulai kehilangan fungsi sosialnya. tuntunan agama yang 
Siti Amalia

mengajarkan untuk hidup damai dan saling mengasihi, berubah menjadi malapetaka yang saling membenci dan menghancurkan. Oleh karenya pembahasan yang akan dikaji dalam artikel ini yaitu: Bagaimana filsafat perenial dalam menjelaskan hakikat agama? Permasalahan ini akan peneliti kaji dengan pendekatan deskriptif, hermeneutika, dan kesinambungan historis. Hakikat agama dalam perspektif filsafat perenial dapat dilihat dari dua sisi yakni eksoterik dan esoterik. Sisi eksoterik melihat hakikat agama dari segi bentuk yang terkait dengan historisitas, kebudayaan, adat istiadat, dan suku dalam masyarakat tertentu. Sedangkan sisi esoterik melihat hakikat agama dengan mencari titik temu untuk menelusuri matarantai historisitas tentang pertumbuhan agama. Titik temu tersebut adalah terletak pada tataran substansi yang memiliki kesatuan transendent. Sehingga, dari sisi esoterik hakikat agama adalah satu tidak terbagi, tetapi dari yang satu ini memancarkan berbagai kebenaran. Ketika hakikat agama dilihat pada perbedaan bentuk, maka hal tersebut adalah bernilai relatif, karena masing-masing penganut agama memiliki klaim eksklusif tentang agama yang dianut. Namun ketika agama dilihat dalam kesatuan transendent, itulah yang disebut kebenaran absolut.

Kata kunci: Filsafat Perenial, Agama

\section{A. Pendahuluan}

Kepercayaan pada adanya yang gaib merupakan dasar yang utama sekali dalam faham keagamaan. Kekuatan gaib itu, kecuali dalam agama-agama yang bersifat primitif disebut dengan Tuhan. Agama-agama primitif belum memberi nama Tuhan kepada kekuatan gaib itu. Kekuatan gaib belum mempunyai arti theisme atau deisme, tetapi masih kepada dinamisme dan animisme. ${ }^{1}$ Dinamisme adalah kepercayaan adanya kekuatan pada sebuah benda, ${ }^{2}$ sedangkan animisme adalah kepercayaan akan adanya kekuatan pada roh. ${ }^{3}$

Kepercayaan akan adanya kekuatan gaib selanjutnya meningkat pada polytheisme yaitu adanya banyak dewa yang berkuasa di alam semesta. Dalam polytheisme, dewa-dewa mempunyai kepribadian, sehingga setiap dewa memiliki tugas masing-masing dalam kehidupan. Terdapat pula pada suatu masa

\footnotetext{
${ }^{1}$ Harun Nasution, Falsafat Agama (Jakarta: Bulan Bintang, 1975), h. 23.

${ }^{2}$ Ibid., h. 24.

3 Ibid., h. 27.
} 
dalam perkembangan paham keTuhanan, hanya satu dewa saja yang diberikan kedudukan tertinggi diantara Tuhan yang banyak, paham tersebut adalah henoteisme. Henoteisme hanya perlu selangkah untuk meningkat menjadi monotheisme. Kalau Tuhan-Tuhan asing yang disangka musuh atau saingan itu tidak diakui lagi, yang ada hanya kepercayaan kepada satu Tuhan, yaitu satu Tuhan untuk seluruh manusia, satu Tuhan yang menjadikan seluruh kosmos ini. Tidak ada Tuhan selain Dia. ${ }^{4}$

Agama merupakan jalan yang diambil sebagai alternatif bagi seseorang untuk mendapatkan keselamatan dalam hidupnya. Keyakinan akan adanya kekuatan maha tinggi, yang mengatur jalannya kehidupan memang sudah seharusnya dipercayai oleh manusia. Karena sesuatu yang "ada" pasti ada yang menciptakan. Dan yang menciptakan memiliki kedudukan lebih tinggi dari yang diciptakan. Beragama harus dimulai dengan keimanan kepada Tuhan. Mengimani Tuhan berarti meyakini eksistensi dan sifat-sifat-Nya. ${ }^{5}$

Membuktikan kebenaran suatu keyakinan, tentu tidak harus menyatakan bahwa keyakinan yang lain salah dan sesat. Pola pandang dominatif bukan saja gagal dalam mengemban misi agama, tapi juga menyimpang dari tujuan luhur agama-agama untuk mewujudkan tatanan kehidupan yang damai dan harmoni. Para Nabi tidak bermaksud membentuk agama identitas (Religion of Identitif) melainkan agama kebenaran (Religion of truth). Umat beragama memang selalu dalam posisi mencari dan tidak memonopoli kebenaran. Sebab, manakala mereka merasa telah menggenggam kebenaran, maka saat itu pula mereka mengalami krisis identitas. ${ }^{6}$

Terdapatnya perbedaan yang tumbuh di dalam agama menyebabkan pergeseran makna dan fungsi agama yang sebenarnya. Agama yang senantiasa mengajarkan hidup damai dan sejahtera ternyata disisi lain merupakan salah satu faktor yang memberikan pengaruh besar pada kekerasan dan konflik. Kondisi demikian disebabkan karena kurangnya pemahaman yang universal para penganut agama, sehingga terkonstruk dalam fikirannya sebuah

\footnotetext{
4 Ibid., h. 30-34.

5 Idrus Shahab, Beragama dengan Akal Jernih (Jakarta: Serambi, 2007), h. 57.

6 Mun'im A. Sirry, Membendung Militansi Agama Iman dan Politik dalam Masyarakat Modern (Jakarta: Erlangga, 2003), h.133-134.
} 
anggapan bahwa agama yang dianut adalah satu-satunya agama yang memiliki sumber kebenaran.

Sejak tahun 1996, konteks kehidupan antar umat beragama di Indonesia memasuki periode yang buram. Kerusuhan di Situbondo pada bulan oktober 1996 belum tuntas diusut, pada penghujung bulan desember 1996 muncul kerusuhan serupa di Tasikmalaya hingga pecahnya tradisi Ambon yang bertepatan dengan Hari raya Idul Fitri tahun 1998. ${ }^{7}$ Ditambah lagi dengan kasus-kasus yang terjadi tahun 2018 silam seperti kerusuhan di Mako Brimob dan beberapa bom bunuh diri di beberapa gereja di Surabaya. Masih terekam jelas bahwa dengan melegitimasi agama dan bentuk jihad yang diyakini oleh Pemahaman agama yang kacau menyebabkan terjadinya radikalisme.

Deretan peristiwa tersebut nyatalah bahwa Sikap keberagamaan yang hanif tidak lagi tercermin dalam kehidupan. Tumbuhnya sikap saling memusuhi bahkan merusak sudah tidak terhindar lagi. Akibatnya bukan saja dari individu ke individu, tetapi juga kelompok dan lingkungan.

Pembahasan mengenai hakikat agama tentu telah banyak yang mengkaji, diantaranya: Sidi Ghazalba, menyatakan bahwa yang dimaksud dengan agama adalah hubungan manusia dengan yang maha kudus. Hubungan yang menyatakan diri dengan bentuk kultus ritus dan sikap hidup berdasarkan doktrin-doktrin tertentu. ${ }^{8} \mathrm{~K}$ Sukardji, mengutip pendapat Alfred Whitehead seorang orientalis Barat menyebut agama sebagai religie, yaitu sebagai suatu sistem kebenaran umum yang membawa akibat berubah watak manusia bila benar-benar dipegangi sepenuhnya. Batasan yang diungkapkannya menunjukkan kebenaran secara universal sebagai tanda kemahakuasaan Tuhan. ${ }^{9}$ Sedangkan Menurut A.M. Saefuddin agama merupakan kebutuhan paling esensial manusia yang bersifat universal. Karena itu agama menurutnya adalah kesadaran spiritual yang di dalamnya ada satu kenyataan di luar kenyataan yang tampak ini, yaitu bahwa manusia selalu mengharap belas kasih-Nya, bimbingan tangan-Nya, serta belaian-Nya, yang secara ontologis

7 Muhammad Sofyan, Agama dan Kekerasan dalam Bingkai Reformasi (Yogyakarta: Media Pressindo, 1999), h. 7.

${ }^{8}$ AH Hasanudin, Cakrawala Kuliah Agama (Surabaya: Al-Ikhlas, 1980), h. 81.

9 K Sukardji, Agama-agama yang Berkembang di Dunia dan Pemeluknya, h.32 
tidak bisa diingkari walaupun oleh manusia yang komunis sekalipun. ${ }^{10}$ Selanjutnya didalam buku Amsal Bakhtiar mengutip pendapat Max Mulller, definisi agama secara lengkap belum tercapai karena penulisan terhadap agama terus dilakukan dan para ahli agama masih menyelidiki asal-usul agama. Jadi definisi agama yang pasti dan lengkap tentang agama belum terealisir. Kendati Max Muller mengatakan bahwa definisi agama belum lengkap, namun dari definisi yang sudah dijelaskan beberapa unsur pokok dalam agama telah terungkap yaitu masalah yang gaib. Adanya hubungan baik dengan kekuatan gaib tersebut, maka muncullah respon emosional dari manusia, baik respon dalam bentuk rasa takut, atau perasaan cinta, dan adanya yang suci, seperti kitab suci atau tempat suci. ${ }^{11}$

Dalam artikel ini akan membahas bagaimana hakikat agama dalam perspektif filsafat perenial? Permasalahan ini akan peneliti kaji dengan menggunakan metode deskriptif, hermeneutika, dan kesinambungan historis. Untuk menjalin hubungan baik dengan Tuhan, maka diperlukan jalan keselamatan yaitu agama. Kesalahpahaman dalam memaknai agama tidak dapat dibiarkan begitu saja, pendekatan dengan menggunakan perspektif filsafat perenial kiranya cocok untuk menjelaskan bagaimana hakikat agama. Karena filsafat perenial memiliki kajian yang universal dalam memahami agama.

\section{B. Tinjauan Teoritis Tentang Hakikat Agama}

Terdapat banyak rumusan dan perbedaan dalam membahas tentang agama. Ada yang diungkapkan secara global dan ada pula yang oprasional. Demikian pula isi yang terkandung didalamnya, ada yang mencakup seluruh aspek kehidupan dan ada pula yang hanya menyebutkan sebagian saja. Perbedaan tersebut dipengaruhi oleh pandangan hidup, pengalaman, latar belakang pendidikan, dan disiplin ilmu yang berbeda dari tokoh yang merumuskannya.

Kata "agama" oleh orang Barat disebut religie atau religion. Kemudian bangsa Arab dan bangsa-bangsa selain Arab yang berbahasa dengan bahasa Arab menyebutnya dengan ad-dien. Selain

\footnotetext{
${ }^{10}$ Amsal Bakhtiar, Filsafat Agama Wisata Pemikiran dan Kepercayaan Manusia, h. 12 .

11 Ibid.,h. 14.
} 
para pemeluk agama Islam yang berbahasa dengan bahasa Arab menyebut agama dengan millah dan mazhab. Menurut etimologi, agama berasal dari bahasa Sansekerta yang tersusun dari kata "a" berarti tidak dan "gam" berarti pergi. Sehingga agama berarti tidak pergi, tetap ditempat, langgeng, abadi, diwariskan secara terus menerus dari generasi ke generasi. Namun pada umumnya perkataan agama diuraikan dengan "a" berarti tidak dan "gama" berarti kacau. Maksudnya orang yang memeluk agama dengan sungguh-sungguh hidupnya tidak kacau. ${ }^{12}$

Sedangkan menurut istilah, dikutip dari pendapatnya Sidi Ghazalba, bahwa yang dimaksud dengan agama adalah hubungan manusia dengan yang maha kudus. Hubungan yang menyatakan diri dengan bentuk kultus ritus dan sikap hidup berdasarkan doktrindoktrin tertentu. ${ }^{13}$ Selain itu, Alfred Whitehead seorang orientalis Barat menyebut agama sebagai religie, yaitu sebagai suatu sistem kebenaran umum yang membawa akibat berubah watak manusia bila benar-benar dipegangi sepenuhnya. Batasan yang diungkapkannya menunjukkan kebenaran secara universal sebagai tanda kemahakuasaan Tuhan. ${ }^{14}$

Sejarah agama lahir sebagai bentuk pembebasan dari penderitaan dan penindasan kekuasaan untuk kedamaian hidup. Semua bentuk agama dimaksudkan agar manusia dapat hidup bebas di hadapan Tuhan-Nya secara benar yang diaktualisasikan dengan taat kepada hukum, saling menyayangi, adil, dan menjaga diri dari perbuatan yang tidak baik. Semua hal tersebut disampaikan secara jelas dalam kitab suci agamanya masing-masing. ${ }^{15}$

Menurut Max Mulller definisi agama secara lengkap belum tercapai karena penulisan terhadap agama terus dilakukan dan para ahli agama masih menyelidiki asal-usul agama. Jadi definisi agama yang pasti dan lengkap tentang agama belum terealisir. Kendati Max Muller mengatakan bahwa definisi agama belum lengkap, namun dari definisi yang sudah dijelaskan beberapa unsur pokok dalam agama telah terungkap yaitu masalah yang gaib. Adanya hubungan baik

${ }^{12}$ K Sukardji, Agama-agama yang Berkembang di Dunia dan Pemeluknya (Bandung: Angkasa, 2007), h. 26.

${ }^{13}$ AH Hasanudin, Cakrawala Kuliah Agama (Surabaya: Al-Ikhlas, 1980), h. 81.

${ }_{14}$ K Sukardji, Agama-agama yang Berkembang di Dunia dan Pemeluknya, h.32

${ }_{15}$ Maskudin, Paradigma Agama dan Sains Nondikotomik (Yogyakarta: Pustaka Pelajar,2013), h. 39-40. 
dengan kekuatan gaib tersebut, maka muncullah respon emosional dari manusia, baik respon dalam bentuk rasa takut, atau perasaan cinta, dan adanya yang suci, seperti kitab suci atau tempat suci. ${ }^{16}$

Dari beberapa uraian di atas, dapat ditarik benang merah bahwa agama merupakan jalan keselamatan dan hubungan antara manusia dengan Tuhan, yang berisi tentang ajaran-ajaran, hukum, maupun aturan yang memiliki sifat mengikat. Aturan tersebut dibuat oleh Tuhan yang memiliki kekuatan melebihi segala hal yang ada, melalui wahyu yang disampaikan kepada utusan-Nya berupa doktrindoktrin agama dan kitab suci. Agama menjelaskan tentang hal-hal yang bersifat gaib dibalik alam materi. Beberapa ciri-ciri agama antara lain percaya kepada yang kudus, melakukan hubungan dengan yang kudus berupa ritus (upacara) dan kultus (pemujaan, penyembahan), permohonan, doktrin yang mengajarkan kepercayaan dan selanjutnya memberikan sebuah sikap hidup seseorang dalam kesehariannya.

Berbagai cara ditunjukkan oleh seseorang yang telah menyatakan dirinya menganut suatu agama. Mengapa manusia beragama secara umum dijelaskan oleh Am. Hardjana dalam bukunya yang berjudul "penghayatan agama". Bahwa ada enam faktor yang mendorong manusia untuk beragama, yaitu untuk mendapatkan keamanan, mencari perlindungan dalam hidup, menemukan penjelasan atas dunia dan hidup serta segala yang termaktub di dalamnya, memperoleh pembenaran atas praktik-praktik hidup yang ada, meneguhkan tata nilai yang sudah mengakar dalam masyarakat, dan memuaskan kerinduan hidup. ${ }^{17}$

Tidaklah sepenuhnya salah ketika Sigmund Freud atau Karl Mark berteori bahwa kebutuhan untuk ber-Tuhan ataupun beragama muncul ketika seseorang ditimpa malapetaka. Keyakinan tentang Tuhan hanyalah produk dari situasi tak berdaya, ketika seseorang tidak mampu lagi keluar dari derita. Jika kita ikuti argumen mereka dan dalam konteks apa mereka berbicara, bisa jadi kita pun sepaham dengannya. Karena sebenarnya ketika Mark berbicara tentang Tuhan dan Agama, baik Mark maupun Freud tidaklah berangkat dari dalil-

16 Amsal Bakhtiar, Filsafat Agama Wisata Pemikiran dan Kepercayaan Manusia (Jakarta: Rajawali Pers, 2014), h. 14.

${ }^{17}$ Am. Hardjana, Penghayatan Agama yang Otentik dan Tidak Otentik (Yogyakarta: Kanisius, 1993), h. 15. 
dalil kitab suci dan tidak pula teologi, melainkan dengan mengamati situasi konkrit manusia yang secara psikologis merasa tertindas oleh situasi sosial dan politik. Mark, misalnya terpanggil untuk membela mereka yang tertindas secara politis dan ekonomis, ketika lembaga dan penguasa menurutnya hanya memberi hiburan semu, janji-janji surga di seberang derita. Bahkan Mark lebih kesal ketika agama dan para tokohnya telah berkolusi dengan penguasa untuk menindas rakyat. $^{18}$

Menurut A.M. Saefuddin agama merupakan kebutuhan paling esensial manusia yang bersifat universal. Karena itu agama menurutnya adalah kesadaran spiritual yang di dalamnya ada satu kenyataan di luar kenyataan yang tampak ini, yaitu bahwa manusia selalu mengharap belas kasih-Nya, bimbingan tangan-Nya, serta belaian-Nya, yang secara ontologis tidak bisa diingkari walaupun oleh manusia yang komunis sekalipun. ${ }^{19}$

Hidup di dunia ini sungguh sangat menarik, tidak selalu aman, alam tidak selalu ramah, baik dan simpatik terhadap manusia. Maka dari itu manusia berpaling pada agama dengan pergi menghadap kepada Tuhan, Sang Pemberi dan Pemelihara kehidupan. Dalam mengarungi hidupnya manusia akan mengarah ke depan, baik yang sekedar mengikuti arus atau yang memiliki rancangan hidup, maka dari itu manusia memerlukan perlindungan dari kekuatan yang maha kuasa sehingga membawanya pada kepercayaan terhadap agama.

\section{Memahami Filsafat Perenial dan Perkembangannya}

Dalam perkembangan ilmu kefilsafatan, Komar dan Nafis menulis pendapat Huston Smith dalam sebuah karyanya yang menyatakan tentang adanya dua corak filsafat yang sangat kontras, yaitu filsafat tradisional dan filsafat modern. Filsafat tradisional atau yang lebih dikenal dengan filsafat perenial selalu membicarakan tentang adanya "Yang Suci" atau "Yang Satu", sedangkan filsafat modern justru sebaliknya yaitu membersihkan "Yang Suci" dari alam

${ }^{18}$ Komaruddin Hidayat, Tragedi Raja Midas Moralitas Agama dan Krisis Modernisme (Jakarta: Paramadina, 1998), h. 42.

Manusia, h. 12.

19 Amsal Bakhtiar, Filsafat Agama Wisata Pemikiran dan Kepercayaan 
fikiran. ${ }^{20}$ Selanjutnya masih dalam sumber yang sama, Arthur J. D'Adamo, menyatakan bahwa:

"Tidak seperti agama yang menuntut iman terlebih dahulu (secara dogmatis), yang lepas atau malah bertentangan dengan pengertian, sains mencari pengertian terlebih dahulu. Dalam sains keyakinan didasarkan pada pengertian. Sedangkan dalam agama pengertian itu didasarkan pada keyakinan iman". ${ }^{21}$

Filsafat perennial atau Philosophia perenis secara harfiah memiliki arti filsafat yang abadi. Menyangkut kata "abadi" ini, ada dua macam interpretasi yang berbeda. Pertama, sebagai nama diri (proper name) dari suatu tradisi filsafat tertentu. Kedua sebagai sifat yang menunjuk pada sistem filsafat yang memiliki keabadian ajaran, apapun namanya. ${ }^{22}$ Jaspers tidak menerima filsafat perenial sebagai suatu sistem. Ia berpendapat bahwa pada dasarnya filsafat apapun bentuk dan jenisnya adalah perenial atau abadi. Pandangan Jaspers diperkuat oleh James Collins, yang dengan tegas menolak pemakaian istilah filsafat perenial sebagai proper name dari suatu sistem filsafat tertentu. Istilah filsafat perenial menurutnya adalah kata sifat, yaitu filsafat yang perenial atau filsafat yang abadi. ${ }^{23}$

Berbeda dari Karl Jaspers, ada seorang tokoh yaitu Charles B. Schmitt yang justru menganggap istilah filsafat perenial sebagai suatu proper name yaitu nama suatu sistem filsafat tertentu. Schmitt menyebutkan bahwa sejak kemunculan pola-pola pemikiran filsafat perenial pada zaman dahulu (masa para pemikir awal), baru pada abad ke-16, istilah filsafat perenial dipakai sebagai nama sistem filsafat. Istilah perenial dari jenis filsafat ini menurut Schmitt bermakna bahwa filsafat ini tetap bertahan terus sepanjang zaman dan kesejatiannya dapat diwariskan dari generasi ke generasi serta dapat melampaui kecenderungan corak filsafat yang silih berganti. ${ }^{24}$

20 Komaruddin Hidayat, Muhammad Wahyuni Nafis, Agama Masa Depan Perspektif Filsafat Perennial (Jakarta: Paramadina, 1995), h. xxi.

${ }^{21}$ Ibid., h. xxvi.

22 Ahmad Norma Permata, "Antara Sinkretis dan Pluralis: Perenialisme Nusantara". Perenialisme Melacak Jejak Filsafat Abadi, ed. Ahmad Norma Permata (Yogyakarta: PT Tiara Wacana Yogya, 1996), h. 2.

${ }^{23}$ Emanuel Wora, Perenialisme Kritik Atas Modernisme dan Postmodernisme (Yogyakarta: Kanisius, 2006), h. 11-12.

${ }^{24}$ Ibid, h. 13. 
Filsafat perenial merupakan sebuah wacana filsafat yang tua, yang ada pada masa pra modern, namun diklaim sebagai yang tetap aktual sepanjang masa. Ada perbedaan pandangan diantara para tokoh berkenaan dengan awal kemunculan filsafat perenial. Satu pendapat mengatakan bahwa istilah filsafat perenial berasal dari Leibniz yang ditulis dalam surat untuk temannya Remundo tanggal 26 agustus 1714 dan selanjutnya dipopulerkan oleh Huxley. Meskipun demikian, Leibniz tidak pernah menerapkan istilah tersebut sebagai nama terhadap sistem filsafat siapapun termasuk sistem filsafatnya sendiri. ${ }^{25}$

Selanjutnya pandangan lain yang menyangkal bahwasannya sebelum Leibniz ada seorang tokoh yang lebih dahulu menggunakan istilah filsafat perenial yaitu Agostino Steuco dalam karyanya berjudul "De Perenni Philosophia" pada tahun 1540. Buku tersebut merupakan upaya untuk mensintesiskan antara filsafat, agama dan sejarah berangkat dari sebuah tradisi filsafat yang sudah mapan. Dari tradisi tersebut Augustino berusaha mencoba mensintesiskan terhadap filsafat, agama dan sejarah yang diberi nama philosophia perenis. ${ }^{26}$

Menurut Huston Smith terdapat dua tradisi besar filsafat yang sangat kontras, yaitu "Filsafat Modern" dan "Filsafat Tradisional". Filsafat tradisional atau yang lebih dikenal dengan filsafat perenial selalu membicarakan tentang adanya "Yang Suci" (The Sacred) atau "Yang Satu" (The One) dalam seluruh manifestasinya, seperti dalam agama, filsafat, sains dan seni. Sedangkan filsafat modern justru sebaliknya membersihkan "Yang Suci" dan "Yang Satu". Mereka tidak hanya memisahkan persoalan spiritualitas dari keduniawian, bahkan ingin menghilangkan sama sekali. ${ }^{27}$

Perkembangan filsafat perenial menurut Griffiths mengalami masa kejayaannya kira-kira antara abad ke-6 hingga abad ke-15, yang tidak hanya terjadi di dunia Barat dan dalam konteks Kristianitas saja, melainkan juga terjadi di wilayah lain dunia serta dalam konteks

25 Arqom Kuswanjono, Ketuhanan dalam Telaah Filsafat Perenial Refleksi Pluralisme Agama (Yogyakarta: CV Arindo Nusa Media, 2006), h. 10.

26 Charles B Schmith, "Filsafat Perenial dari Steuco Hingga Leibniz". Perenialisme Melacak Jejak Filsafat Abadi, ed.Ahmad Norma Permata (Yogyakarta: PT Tiara Wacana Yogya, 1996), h. 34. Lihat juga Arqom Kuswanjono, Ketuhanan dalam Telaah Filsafat Perenial ......, h. 11.

27 Komaruddin Hidayat, Muhammad Wahyuni Nafis, Agama Masa Depan Perspektif Filsafat Perennial, h. xxii. 
agama lain pula, walaupun memang perkembangannya lebih tampak di dunia Barat. Augustino Steuco yang merupakan seorang perenialis dari abad Renaisans dan juga seorang sarjana alkitab dan teolog. Karyanya mempengaruhi banyak orang antara lain Ficino dan Pico. Bagi Ficino filsafat perenial disebutnya sebagai filsafat kuno yang antik (philosophia priscorium). ${ }^{28}$

Filsafat perenial dalam pembicaraan ini tidak dipahami sebagai paham atau filsafat yang berpandangan bahwa semua agama adalah sama. Suatu pandangan yang samasekali tidak menghormati religiusitas yang partikular. Akan tetapi filsafat perenial yang berpandangan bahwa Kebenaran Mutlak (the truth) hanyalah satu, tidak terbagi, tetapi dari Yang Satu ini memancar berbagai "kebenaran". Sebagaimana matahari yang secara niscaya memancarkan cahayanya. Hakikat cahaya adalah satu dan tanpa warna tetapi spektrum kilatan cahayanya ditangkap oleh mata manusia dalam kesan yang beraneka warna. ${ }^{29}$

Menurut Huxley ada tiga konsep dasar filsafat perenial, yaitu: pertama metafisika yang memperlihatkan suatu hakikat kenyataan Ilahi dalam kehidupan dan pikiran. Kedua, psikologi yang memperlihatkan adanya sesuatu dalam roh/ jiwa manusia yang identik dengan kenyataan Ilahi itu. Ketiga, etika yang meletakkan tujuan akhir manusia dalam pengetahuan akan dasar semua yang ada, yang bersifat imanen maupun transenden. ${ }^{30}$

Filsafat perennial bisa juga disebut sebagai tradisi dalam pengertian al-Din, al-Sunnah dan al-Silsilah. Al-din dimaksud adalah sebagai agama yang meliputi semua aspek kehidupan dan percabangannya. Disebut al-Sunnah karena filsafat perennial mendasarkan segala sesuatu atas model-model sakral yang sudah menjadi kebiasaan turun temurun di kalangan masyarakat tradisional. Disebut al-Silsilah karena filsafat perenial juga merupakan rantai yang mengaitkan setiap periode, episode atau tahap kehidupan dan pemikiran di dunia tradisional kepada sumber segala sesuatu, seperti terlihat didalam dunia tasawuf. Karenanya filsafat perennial dalam

${ }^{28}$ Emanuel Wora, Perenialisme Kritik Atas Modernisme dan Postmodernisme, h.

18.

${ }^{29}$ Komaruddin Hidayat, Muhammad Wahyuni Nafis, Agama Masa Depan ...., h.

6.

${ }^{30}$ Ibid., h. xxix.

IJITP, Vol. 1, No. 1 Tahun 2019 
pengertian tradisi ini, Nasr mengungkapkannya dengan menggambarkannya sebagai sebuah pohon, akar-akarnya tertanam melalui wahyu di dalam sifat Illahi dan darinya tumbuh batang dan cabang-cabang sepanjang zaman. ${ }^{31}$

Kaum perenialis menggunakan pendekatan mistik untuk memahami realitas agama dan keberagamaan yang begitu kompleks, serta berusaha melacak akar religiusitas dari berbagai bentuk agama di dalam memahami aspek ketuhanan dan secara ideal berusaha menemukan titik-titik simpul keragaman pemahaman itu, sehingga ditemukan pemahaman transendental tentang Yang Satu. Secara eksistensial Tuhan adalah tunggal. Persoalan yang akan muncul adalah mengapa dari yang Tunggal itu, dalam realitas konkrit muncul pemahaman yang plural? Jawaban atas persoalan ini bagi kaum perenialis tentunya tidak dapat hanya dipahami secara logis rasional semata, namun sangat diperlukan pemahaman yang bersifat mystical. ${ }^{32}$ Begitu pula dalam memahami keberagamaan bentuk yang ditampilkan agama. Secara metafisik dinyatakan, hanya realitas puncaklah yang absolut dan sekaligus wajib murni dan bebas murni. Hanya Tuhan yang secara sempurna wajib dan bebas, wujud yang absolut dan tak terbatas. ${ }^{33}$

\section{Memahami Hakikat Agama dari Filsafat Perenial}

Ketika berbicara tentang agama, disitu terdapat dua pengertian penting yang harus dijelaskan. Pertama, agama sebagai suatu doktrin dan ajaran yang temuat dalam kitab suci. Kedua, agama sebagai aktualisasi dari doktrin tersebut yang terdapat dalam sejarah. Para pemeluk agama diharapkan untuk melaksanakan ajaran dengan baik, namun kenyataannya seringkali jauh dari yang dikehendaki. Karenanya agama sering kali menampakkan diri dengan wajah ganda. Artinya sesuatu yang terjadi berbeda jauh dari yang sebenarnya dimaksud oleh agama. Misalnya semua agama menyeru untuk perdamaian, persatuan dan persaudaraan. Tetapi pada kenyataannya,

31 Metz Muntsani, "Gagasan-Gagasan Filsafat Perennial" (On-line), tersedia di:https://bismirindu.wordpress.com/2009/07/23/filsafat-perennial-2/ (21 april 2015).

h. 73 .

32 Komaruddin Hidayat, Muhammad Wahyuni Nafis, Agama Masa Depan ....,

33 Sayyed Hossein Nasr, Inteligensi \& Spiritualitas Agama-agama (Jakarta: Inisiani Press,2004), h.151. 
agama menampilkan diri dalam kekuatan yang garang, penyebar konflik, bahkan tak jarang berujung pada peperangan. ${ }^{34}$

Kontribusi agama dalam memecahkan problema sosial tidaklah mudah, apalagi dari hari ke hari tantangan-tantangan yang dihadapi semakin berat dan kebutuhan manusia pun semakin banyak. Agama dengan tuntunan kitab suci harus mampu memberikan jalan keluar yang realistis terhadap problema-problema dalam masyarakat yang beraneka ragam. ${ }^{35}$

Agama merupakan petunjuk bagi umat manusia untuk menyebarkan perdamaian dan memberikan solusi terhadap persoalan kehidupan. Namun, ketika agama dilibatkan justru persoalan menjadi semakin meruncing, bahkan mereka (para penganut agama) rela saling membunuh atas nama agama yang diyakininya. Kondisi demikian tidak menutup kemungkinan akan memunculkan sikap tidak percaya terhadap fungsi/ manfaat agama dalam rangka mengatasi persoalan-persoalan kehidupan, yang oleh Komarudin Hidayat dikatakan sebagai kegagalan peran sosial agama. ${ }^{36}$

Sejak dulu, pertemuan antara penganut berbagai agama telah terjadi. Dari perjumpaan itu telah dihasilkan banyak kerja sama, namun tidak sedikit pula yang mengakibatkan perselisihan, bahkan peperangan. Dari sudut keyakinan, perselisihan antar pemeluk agama biasanya terjadi akibat klaim kebenaran (truth claim) dan klaim keselamatan (salvation claim) yang dimiliki. Pada awalnya, klaim yang bersifat eksklusif tersebut merupakan penegasan akan identitas khas suatu kelompok agama yang berbeda dengan agama kelompok lain. Tetapi dalam perkembangan selanjutnya, suatu kelompok agama berusaha menunjukkan, bahkan memaksakan, klaim keselamatan eksklusif tersebut pada orang lain yang sebenarnya juga telah memiliki suatu klaim keselamatan eksklusif. Pertentangan klaim eksklusif inilah yang merupakan salah satu sebab, di samping sebabsebab yang lain, timbulnya perpecahan antar agama. ${ }^{37}$

Dihadapkan dengan klaim-klaim kebenaran tersebut, studi filsafat mengajak manusia bersama-sama menguji ulang berbagai

${ }^{34}$ Afif Muhammad, Agama dan Konflik Sosial (Bandung: Marja, 2013), h. 17.

35 Nur Solikin, Agama dan Problem Mondial (Yogyakarta: Pustaka Pelajar, 2013), h. vii.

${ }^{36}$ Arqom Kuswanjono, Ketuhanan dalam ...., h. 3.

37 Ali Noer Zaman, Agama Untuk Manusia (Yogyakarta: Pustaka Pelajar, 2000), h. vi. 
klaim kebenaran. Tujuannya adalah menambah wawasan keluasan dan keluwesan intelektual, menumbuhkan sikap toleransi terhadap berbagai pendapat dan keyakinan hidup, dan membebaskan sikap eksklusif yang menyatu dalam keyakinan hidup. Sehingga untuk memahami agama, tidak hanya cukup pada dataran normatif tetapi juga dengan melihat historisitas. ${ }^{38}$

Hakikat agama dalam perspektif filsafat perenial dapat dilihat dari dua sisi yakni eksoterik dan esoterik. Schuon menarik garis pemisah antara eksoterik dengan esoterik. Eksoterik (exoteric) adalah hal-hal yang boleh diketahui dan dilakukan oleh semua anggota kelompok penganut suatu paham tertentu, sedangkan esoterik (esoteric) adalah hal-hal yang hanya boleh diketahui dan dilakukan beberapa orang saja dari suatu kelompok penganut paham tertentu. Dalam tesis Schuon juga dijelaskan secara esoterik semua agama pada dasarnya atau pada hakikatnya sama. Namun secara eksoterik yang membuat berbeda adalah bentuknya. ${ }^{39}$

Filsafat perenial sering memberikan analog tentang Yang Mutlak seperti halnya cahaya matahari yang satu dan ketika ditangkap oleh prisma memunculkan beraneka macam warna. Setiap warna satu dengan yang lain adalah sebagai pancaran/ bagian dari yang satu, yang tidak dapat mengklaim bahwa dirinya adalah "Yang Mutlak", ia hanyalah secara relatif mutlak. Semua warna berasal dari yang satu sebagaimana agama yang berasal dari "Yang Satu", namun ketika ditangkap oleh sejarah dan kebudayaan memunculkan berbagai warna yang berbeda-beda. Perbedaan yang ada dalam hal ini berada pada dataran yang eksoterik, yang sesungguhnya mempunyai kesatuan transendental pada dataran esoterik. ${ }^{40}$

Di zaman pascamodern ini manusia semakin dihadapkan dengan kenyataan bahwa setiap agama akan bertemu dengan agamaagama lain, sehingga ia harus mendefenisikan secara teologis dan metafisik tentang bagaimana hubungannya dengan agama lain. Filsafat perenial membantu menjelaskan kejadian yang bersifat hakiki, menyangkut kearifan yang diperlukan dalam menjalankan

${ }^{38}$ M. Amin Abdullah, Studi Agama Normativitas dan Historisitas (Yogyakarta: Pustaka Pelajar, 2002), h.52. 2003), h. 11.

${ }^{39}$ Frithjof Schuon, Mencari Titik Temu Agama-agama (Jakarta: Pustaka Firdaus,

${ }^{40}$ Arqom Kuswanjono, Ketuhanan dalam ...., h. 77 
hidup yang benar yang rupanya menjadi hakikat dari seluruh agamaagama dan tradisi-tradisi besar spiritualitas manusia. ${ }^{41}$

Setiap agama berbicara secara berbeda, tetapi merupakan kebenaran yang sama-sama sah. Setiap agama mengekspresikan bagian penting sebuah kebenaran. Kemajemukan dan pluralitas apabila tidak diimbangi dengan toleransi yang dibangun dengan pemahaman esoterik tentang Tuhan yang benar, dapat menimbulkan truth claim radically dan intoleransi yang sangat membahayakan integritas bangsa. ${ }^{42}$

Pendekatan yang dilakukan filsafat perenial adalah menjelaskan adanya sumber dari segala yang ada, membicarakan tentang realitas absolut. Secara epistemologi, filsafat perenial memberikan jalan menuju pencapaian kepada Yang Absolut tersebut melalui pendekatan mistik yaitu melalui intelek yang lebih tinggi di dalam memahami secara langsung tentang agama. Pendekatan mistik yang dilakukan filsafat perenial tidak hanya melalui perenungan reflektif semata, tetapi tetap menggunakan sarana-sarana yang telah ada pada setiap agama berupa ritus-ritus, simbol-simbol, maupun tradisi yang secara esensial berasal dari Yang Satu. ${ }^{43}$ Ketika agama dalam dataran eksoterik menganggap sebagai satu-satunya yang paling benar dan dengan serta merta menyalahkan agama lain, maka agama akan kehilangan esensi sebagai pengendali kekacauan dan justru malah menjadi pemicu perpecahan.

Dalam buku yang ditulis oleh Arqom, Schuon yang mengutip pandangan Nasr mengatakan bahwa: "setiap agama memiliki satu bentuk dan satu substansi. Substansi mempunyai hak yang tidak terbatas, sebab lahir dari yang mutlak, sedangkan bentuk adalah relatif dan karena itu hak-haknya terbatas. Kaum perenis berpendapat bahwa kebenaran mutlak hanya satu tidak terbagi, tetapi dari yang satu ini memancarkan berbagai kebenaran yang berpartisipasi dan bersimbiose dengan dialektika sejarah, sehingga bentuk dan bahasa keagamaan juga mengandung muatan nilai budaya yang berbeda dari suatu komunitas lain. ${ }^{44}$

${ }^{41}$ Komaruddin Hidayat, Muhammad Wahyuni Nafis, Agama Masa Depan.... h. $\mathrm{xx}$.

42 Ibid., h. 5.

43 Ibid., h. 13.

44 Arqom Kuswanjono, Ketuhanan dalam ...., h. 4. 
Dengan demikian, untuk mengkaji prihal agama kita memerlukan dua pendekatan yakni dari sisi bentuk (eksoterik) yang bersifat relatif dan dari sisi substansi yang bersifat mutlak (esoterik). Pada sisi eksoterik, kita akan melihat berbagai macam bentuk yang ditampilkan oleh agama namun setelah masuk pada sisi esoterik kita akan menemukan kesatuan transenden agama-agama yang artinya dalam hal ini meskipun berbeda tetapi memiliki tujuan yang sama yakni kekuatan Yang Satu dan Maha Kuasa.

Hakikat agama adalah keyakinan akan adanya kekuatan gaib yang maha tinggi dan tidak bisa dipisahkan dari kehidupan, maka sangat perlu dipahami secara seksama oleh setiap manusia. Dalam memahami agama kita harus lebih terbuka, maksudnya selain melihat perbedaan bentuk, kita juga harus melihat substansinya. Agar tidak terjebak pada pemahaman yang dangkal tentang agama, sehingga menyebabkan truth claim radically.

Terjadinya periodisasi kenabian dari Nabi Adam sampai Nabi Muhammad bukanlah menunjukkan periodesasi wahyu. Sebagaimana telah dikatakan bahwa Kebenaran Mutlak tidak terikat dimensi ruang dan waktu. Periodesasi kenabian terjadi karena keberadaan para nabi yang bersifat relatif, dan mereka menangkap Kebenaran Mutlak dalam konteks waktu dan tempat masing-masing, sehingga periodesasi kenabian tidak berarti menunjukkan relativitas Kebenaran Wahyu Ilahi yang mereka ajarkan. ${ }^{45}$

Perbedaan eksoterik dan esoterik ibarat mata uang yang tidak dapat dipisahkan satu dengan yang lain. Esoterik meskipun secara substansial adalah universal, pluralitas eksoterik akan terlihat sangat beragam sebagai pengungkapan makna esoterik yang dipahami masing-masing sudut pandang. ${ }^{46}$

\section{E. Penutup}

Hakikat agama dalam perspektif filsafat perenial dapat dilihat dari dua sisi yakni eksoterik dan esoterik. Eksoterik memandang agama dari latar belakang historis, budaya, dan suku pada masyarakat tertentu. Wahyu yang diturunkan kepada para Nabi disampaikan menggunakan bahasa yang berbeda, sehingga hal inilah yang

\footnotetext{
45 Ibid., h. 79.

46 Ibid., h.7.
} 
menyebabkan agama tampil dalam bentuk yang berbeda pula. Kebenaran eksoterik bersifat relatif karena terikat dengan ruang dan waktu. Sedangkan esoterik melihat hakikat agama dengan melihat titik temu pada dataran yang transenden. Sehingga ditemukan satu substansi dari sekian macam bentuk yang ditampilkan oleh agama. Filsafat perenial berpendapat bahwa kebenaran Mutlak hanyalah satu, tidak terbagi, tetapi dari yang satu ini memancarkan berbagai kebenaran. Agama merupakan elemen warna yang satu yang memancar dan ditangkap oleh berbagai kebudayaan, historisitas dan pola fikir yang berbeda. Sehingga dari warna yang satu akan muncul warna yang berbeda. Masing-masing warna tidak dapat mengklaim kebenarannya, karena pada dasarnya warna tersebut memiliki kedudukan yang sama. Seperti halnya agama yang diperoleh melalui pancaran Ilahi yang hadir tidak secara simultan dan melewati keadaan historisitas dan kebudayaan yang berbeda, sehingga menyebabkan perbedaan dalam bentuknya. Namun pada hakikatnya kebenaran agama terdapat pada substansi yang berasal dari satu realitas yang Mutlak. [.]

\section{Daftar Rujukan}

Abdullah, M. Amin. Studi Agama Normativitas dan Historisitas. Yogyakarta: Pustaka Pelajar, 2002.

Bakhtiar, Amsal. Filsafat Agama Wisata Pemikiran dan Kepercayaan Manusia. Jakarta: Rajawali Pers, 2014.

Harahap, Syahrin. Teologi Kerukunan. Jakarta: Prenada, 2011.

Hardjana, Am. Penghayatan Agama yang Otentik dan Tidak Otentik. Yogyakarta: Kanisius, 1993.

Hasanudin, AH. Cakrawala Kuliah Agama. Surabaya: Al-Ikhlas, 1980.

Hidayat, Komaruddin, Muhammad Wahyuni Nafis. Agama Masa Depan Perspektif Filsafat Perennial. Jakarta: Paramadina, 1995.

Tragedi Raja Midas Moralitas Agama dan Krisis Modernisme. Jakarta: Paramadina, 1998. 
Siti Amalia

Kuswanjono, Arqom. Ketuhanan dalam Telaah Filsafat Perenial Refleksi Pluralisme Agama. Yogyakarta: CV Arindo Nusa Media, 2006.

Maskudin. Paradigma Agama dan Sains Nondikotomik. Yogyakarta: Pustaka Pelajar, 2013.

Metz, Muntsani. "Gagasan-Gagasan Filsafat Perennial” (On-line), tersedia di: https://bismirindu.wordpress.com/2009/07/23/ filsafat-perennial-2/ (21 april 2015).

Muhammad, Afif. Agama dan Konflik Sosial. Bandung: Marja, 2013.

Nasr, Sayyed Hossein. Inteligensi \& Spiritualitas Agama-agama. Jakarta: Inisiani Press,2004.

Nasution, Harun. Falsafat Agama. Jakarta: Bulan Bintang, 1975.

Permata, Ahmad Norma. "Antara Sinkretis dan Pluralis: Perenialisme Nusantara". Perenialisme Melacak Jejak Filsafat Abadi, ed. Ahmad Norma Permata. Yogyakarta: PT Tiara Wacana Yogya, 1996.

Schmith, Charles B. "Filsafat Perenial dari Steuco Hingga Leibniz". Perenialisme Melacak Jejak Filsafat Abadi, ed. Ahmad Norma Permata. Yogyakarta: PT Tiara Wacana Yogya, 1996.

Schuon, Frithjof. Mencari Titik Temu Agama-agama. Jakarta: Pustaka Firdaus, 2003.Shahab Idrus. Beragama dengan Akal Jernih. Jakarta: Serambi, 2007.

Sirry, Mun'im. A. Membendung Militansi Agama Iman dan Politik dalam Masyarakat Modern. Jakarta: Erlangga, 2003.

Sofyan, Muhammad. Agama dan Kekerasan dalam Bingkai Reformasi. Yogyakarta: Media Pressindo, 1999.

Solikin, Nur. Agama dan Problem Mondial. Yogyakarta: Pustaka Pelajar, 2013.

Sukardji, K. Agama-agama yang Berkembang di Dunia dan Pemeluknya. Bandung: Angkasa, 2007.

Wora, Emanuel. Perenialisme Kritik Atas Modernisme dan Postmodernisme. Yogyakarta: Kanisius, 2006.

Zaman, Ali Noer. Agama Untuk Manusia. Yogyakarta: Pustaka Pelajar, 2000. 